\title{
A RETROSPECTIVE: THREE QUARTERS OF A CENTURY AT THE HALIFAX FISHERIES RESEARCH LABORATORY
}

\author{
prepared by \\ JAMES E STEWART ${ }^{1 *}$ and ANDREW SAFER ${ }^{2 * *}$ \\ ${ }^{1}$ Science Branch, Department of Fisheries and Oceans \\ Bedford Institute of Oceanography \\ Dartmouth, Nova Scotia B2Y 4A2 \\ 22 Chappell Street \\ Dartmouth, Nova Scotia B3Z 3P2 \\ from contributions by \\ RG Ackman, RF Addison, GAP Black, EG Bligh, JD Castell, JW Cornick, DG Ellis, \\ $P$ Koeller, RE Lavoie, RM Mackelvie, G McClelland, RJ Miller, CM Morrison, G Olivier, \\ GJ Sharp, MJ Tremblay, JF Uthe, NF Watson and P Wiseman
}

In 1925 a Fisheries Technological Program was begun in temporary quarters on the Halifax waterfront to provide scientific research and technical assistance to improve the handling, processing and quality of fisheries products in Atlantic Canada. From that date through to 1979 (with a move to permanent buildings next door) studies on fish processing (smoking, drying, fresh and frozen storage, protein stability, marine oils, enzymatic and bacterial spoilage and grading systems among others) were conducted and the results transferred to industry, government and international agencies with a high degree of success and benefits. After it was apparent that product quality was affected by the condition of fish prior to harvest, more effort was devoted to physiological studies of live fish. In the 1960s studies concerning live lobster storage and latterly technical support for developing aquaculture ventures, i.e. health studies, nutritional requirements, environmental needs and physical structures, were added. Following the termination of the technological program in 1979 the buildings were used to accommodate elements of the Fisheries Resource Branch until they could be re-located in 1997. This retrospective traces the reasons for programs and offers brief sketches of the studies and their application.

En 1925, un programme d'études technologiques sur les pêches voyait le jour dans des locaux provisoires situés sur le front de mer d'Halifax (il a emménagé dans un édifice permanent tout près des locaux originaux par la suite). Le but du programme était d'assurer une aide scientifique et technique afin d'améliorer la manutention, la transformation, et la qualité des produits de la pêche au Canada Atlantique. De 1925 jusqu'en 1979, le programme n'a jamais cessé ses activités. On y a étudié la transformation du poisson (fumage, séchage, entreposage de produits frais ou congelés, stabilité des protéines, huiles marines, détérioration des produits provoquée par des enzymes ou des bactéries et systèmes de classement, entre autres choses), et on a transmis les résultats de ces études à l'industrie, aux gouvernements et aux agences internationales qui en ont retiré de nombreux avantages: Lorsqu'il est devenu évident que la qualité du produit est également influencée par l'état du poisson avant la récolte, on a

** Independent writer and communications consultant 
commencé à consacrer davantage d'efforts aux études physiologiques du poisson vivant. Au cours des années 1960, on a ajouté des études sur les conditions d'entreposage du homard vivant et, plus récemment, on s'est intéressé aux besoins de l'industrie aquacole, à savoir l'état de santé des poissons d'élevage, leurs besoins nutritifs, leurs besoins liés au milieu et les structures physiques. Quand le programme d'études technologiques a pris fin en 1979, les édifices ont été utilisés par certaines composantes de la Direction des ressources halieutiques jusqu'à ce qu'elles aménagent dans d'autres locaux en 1997. Voici une rétrospective de la raison d'être des programmes, des études qui ont été menées et de leurs applications.

\section{INTRODUCTION}

In December 1978 the director of the Halifax Fisheries Laboratory, Dr EG Bligh, was instructed to notify his staff that the Fisheries Technology Branch was to be terminated across Canada at the end of the fiscal year, thereby ending a program begun in 1925. Although it was intended that work at all of the Technological Branch Centres would then cease and the centres be closed, it proved not to be possible immediately at Halifax. There was no other laboratory space available to accommodate the remaining continuing programs of the Fisheries Resource Branch i.e., the Disease and Nutrition Section and the Chemistry Section of the Fisheries and Environmental Sciences Division joined later by the Invertebrates and Marine Plants Division and elements of the Freshwater and Anadromous Division. By October 1997, however, these programs had been re-located and in January 1999 the buildings at 1707 Lower Water Street, Halifax, Nova Scotia by then known as the Halifax Fisheries Research Laboratory, were demolished after close to 70 years of expansions, modifications, renovations and rehabilitations.

Accordingly, this short sketch has been divided into two parts. The first covers the 53 years of the Fisheries Technology Program and the second part, the additional years of the Fisheries Resource Branch Program. Ultimately, following amalgamation of the Fisheries Research Program with the Ocean Science and Surveys Branch (OSS), the combined forces became the current Science Branch of the Department of Fisheries and Oceans (DFO).

\section{THE FISHERIES TECHNOLOGY PROGRAM}

What was the Fisheries Technology Program, what were its objectives and how did it come about? What in particular was its history at the Halifax site? To answer these questions adequately in relation to the Halifax Laboratory it is necessary to delve briefly into the history of the North Atlantic fisheries. 


\section{Historical Background}

The Vikings were among the more daring and wide-ranging of the Atlantic explorers. For their day they ventured incredible distances on voyages lasting lengthy periods. As always on such voyages the supply of food and its preservation was a limiting factor. The Vikings solved this paramount problem through development of fish drying, primarily of cod.

These Viking explorations were followed several centuries later (toward the end of the fifteenth century) by other Europeans whose interests lay in finding a shortcut to the far east and the opportunity to make fortunes from the spice trade (Columbus and Cabot) as well as by the Basques, who may have preceded them, but whose interests lay in the rich fishing grounds. The Basques, in particular, had improved upon the Viking dried cod staple by salting as well as drying the fish. Their markets for fish had been fostered, in particular, by the 'fast (or lean) days' imposed by the medieval Catholic Church, during which meat was prohibited. As the fast days included every Friday, the 40 days of Lent, plus other days on the religious calendar, almost half the days of the year were 'lean days' which eventually became 'salt cod days' thus creating a huge Europe-wide demand for preserved fish. When word reached Britain and Europe generally, via the Cabot expedition, of the tremendous supplies of fish available, the European long distance fishery was initiated and became the basis of many fortunes in Britain, France, Spain and Portugal (Kurlansky 1997).

Thus, when the Atlantic explorations that were intended, initially, to exploit the spice trade with the far East were blocked by the unexpected presence of the Americas, this led in the south to exploitation of the gold and silver of Central and South America while in the north it led to the development of extensive fisheries. The fisheries actually fuelled the initial development and European settlement of North America to a far greater extent than did the fur trade; the importance of the fur trade came later. For example, the burgeoning New England society, based on fishing, led sequentially to agricultural and industrial development further inland. One of the more important fishery products of the $18^{\text {th }}$ and $19^{\text {th }}$ centuries was salted, dried cod. This stable preserved product became a staple and a major trade item sold widely in the Americas and, shamefully was used as part of the currency in the slave trade, in parts of Africa (Johnstone 1977, Kurlansky 1997).

As might be expected the presence of such rich fishing grounds led inevitably to many conflicts, skirmishes and outright wars. The point of importance to our story is that the extensive fishing by all of these national groups using hand methods (largely hook and line) and sailing vessels was, until the middle of the nineteenth century, essentially passive and relatively benign with regard to the impact on fish stocks.

With the advent of steam-powered vessels, however, fishing changed rapidly from a passive to a highly active form through the development and application of trawling techniques. The result, in the latter part of the nineteenth century, was an immense surge in the catches and what came to be recognized as over-fishing; an apparently startling new concept. In fact, 
in 1883, despite evidence to the contrary, the highly influential scientist, Thomas Huxley had declared in the opening address at the International Fisheries Exhibition in London that there was no likelihood of fish scarcity through over-fishing, and that with existing methods of fishing, it was inconceivable that the great sea fisheries, such as those for cod, herring and mackerel, could ever be exhausted (Hubbard 1993). Although over-fishing came to be considered a real problem for fisheries on both sides of the Atlantic, over-fishing did not actually occur in the western Atlantic for some decades. Among the first to write with real insight on the over-fishing problem was Michael Graham (1943).

In the latter part of the $19^{\text {th }}$ century no really clear picture of fish populations, stocks or their dynamics existed. Faced with the decline in catches, those involved in the fisheries cast about for the fundamental causes and arrived at two quite different possible explanations: 1) an actual decline in fish numbers, or 2) changes in availability imposed by alterations in fish migration and aggregation patterns possibly driven by changing oceanographic patterns. As a result two main courses were followed more or less in parallel.

The first was to assume, that as a result of over-fishing, a fish vacuum had been created. It was believed that the area still had all of the ingredients to support the vanished, but desired target species; all that was necessary was to replace the vanished stocks with larvae and young fish that could utilize the presumed huge surpluses of food. To rehabilitate these stocks a number of massive hatcheries were built by the United States at Woods Hole, Boothbay Harbor and Gloucester, by Britain at Dildo; Newfoundland and Dunbar, Aberdeen, Fleetwood and Port Erin in the home islands and by the Norwegians at Flodevigen and Trondheimsfiord (Shelbourne 1964). The program resulted in the release of billions of Gadidae and Pleuronectidae larvae and young fish annually. By World War II or shortly thereafter, lack of evidence of positive results and the high costs led to termination of these attempts to expand marine food fish resources. Some of these hatcheries became the foundation for some of the marine research laboratories of today.

The other part of these more or less parallel thrusts stemmed from the conviction that the problem was not wholly a scarcity of fish, but quite possibly and in part a result of changed migration patterns. As these migration and aggregation patterns were likely to be controlled by oceanographic elements altering environmental conditions, the argument developed early that a major emphasis should be placed on oceanography or as it was then called, hydrography. A coalescence of approaches eventually arose from the debates of the late $19^{\text {th }}$ century concerning the state of commercial fisheries. This amalgam was to include attempts to understand the dynamics of fish production in relation to oceanographic features.

As scientists concerned with marine affairs, including fisheries, were few and far between and the oceans are so large and complex, it was obvious that international cooperation was essential. These debates and the need 
for international cooperation to make effective use of limited resources led rather directly to the foundation in 1902 of the major fisheries umbrella organization the International Council for the Exploration of the Sea (ICES) (Stewart 1991, Rozwadowski 2002) and underscored the need for a scientific underpinning for fisheries. This in turn led to the expansion of studies in those few countries which had work in hand and to the foundation of formal structures in those countries where the effort was minimal or nonexistent, such as Canada (Johnstone 1977). At the time marine biology everywhere consisted largely of taxonomy and descriptive work. Much more was required by all of the fishing nations of the north Atlantic, however, if the devastating economic blow of the decline and failure of the fisheries was to be assuaged. Although there was general recognition that fisheries were in trouble, the fundamental principles governing the production and interactions of fish populations were not understood. It was also recognized that the necessary science to acquire these principles and develop sound management practices, by and large, did not exist. Individual national efforts were either being reinforced or created; although many of these efforts were small, it was not possible then to do much better quickly. Money was scarce, but so were trained people, facilities, equipment, methodology and most importantly the clear objectives upon which to focus activities.

The formal recognition by Canada for the need for science in dealing with the problems of fisheries resulted in the appointment, in 1893, of Dr EE Prince as federal Commissioner of Fisheries. A specialist in fish embryology, he came to the post from the position of Professor of Zoology and Comparative Anatomy at the University of Glasgow. One of his first moves was to advocate a marine scientific station for Canada. In 1898, a memorial, addressed to the Government of Canada, advocating a floating station was approved, money was appropriated and a Board of Management of the Marine Biological Station of Canada was formed (incorporated in 1912 as the Biological Board of Canada). The floating laboratory, completed in June 1899, was located first at St. Andrews and work was begun that summer by three scientists from the University of Toronto, RR and BA Bensley and Joseph Stafford plus the director, EE Prince; with it fairly solid summer programs were conducted through to 1907.

In 1907, the floating station was moved to the north shore of the Gulf of St Lawrence at Seven Islands, then the location of a whaling station. Unfortunately, the scow upon which the laboratory was being carried developed a leak and was beached at Grande Vallée, Québec for repairs. Although the laboratory was then put on shore and repaired, it was eventually abandoned. As the value of a marine laboratory had been proved the Board of Management decided to build a permanent station at St Andrews, New Brunswick. This laboratory was opened in the early summer of 1908 shortly before its newly built west coast sister station at Departure Bay, near Nanaimo, BC.

While studies at these two stations proceeded, work elsewhere had 
been making rapid strides in obtaining knowledge of the oceans and fish resources of northern Europe. Methods of aging fish using scales and otoliths were discovered. In Norway, Johan Hjort had published an important paper 'Fluctuations in the great fisheries of northern Europe' (Hjort 1914). This 228 page paper was one of the most important contributions to fisheries as it united all strands of fisheries science. The central thesis was that fluctuations of fisheries were not caused by over-fishing, migrations or currents, but by the varying success of year classes. A crucial question remaining was what caused good or poor year classes; Hjort regarded the early stages of fish life as critical and believed that fluctuations were closely related to availability of plankton. Thus, Hjort's hypothesis brought together two major lines of endeavour, i.e., fisheries investigations of populations and attempts to quantify the productivity (plankton) of the seas.

The question arose as to whether similar happenings also occurred in the western Atlantic and, if so, were these events synchronized with those in Europe? In 1914, it was decided to invite Dr Hjort to come to Canada to study samples of herring collected from northeastern Newfoundland to Massachusetts. An indication of the success of this visit was an invitation to Dr Hjort to lead a major survey in Canadian waters in 1915, the Canadian Fisheries Expedition. It included Norwegian, Canadian and United States workers and was to determine whether several different races of herring existed, to look for different rates of growth in different waters, to obtain information on year class strengths and past fluctuations in abundance, and to study the regime of ocean temperatures, salinities, currents and plankton contents in east coast waters.

This extensive and intensive venture, the Canadian Fisheries Expedition, was extremely successful and can be regarded as a landmark because of its influence on fisheries and marine sciences in Canada. Not only did it provide an immense amount of information, but it introduced methods of investigation developed in Europe which changed the Canadian style and direction of marine research i.e. combined operations which included physical oceanography, qualitative and quantitative plankton studies, studies of the eggs and larvae of commercial species of fish and detailed herring biology. Unfortunately, the Canadian Fisheries Expedition of 1915 led by Hjort could not be continued in 1916 because of World War I.

Much of Hjort's influence stemmed from the fact that the Expedition greatly impressed a young Canadian participant, AG Huntsman, recently named Permanent Curator of the Biological Station at St Andrews. He was shortly to become Director of the Station and one of the most influential figures over the next 20 years in the Biological Board's research policies. In addition to the object lessons Hjort offered in the area of field studies, Huntsman was also heavily influenced by Hjort's proposals and demonstrations for improving the quality of fishery products so that they would command higher prices in the market place. This in turn provoked interest in fish processing, an element that was to be influential in the eventual establishment of a technological program. At this point the story diverges into several separate branches. Anyone who wishes to have more 
information on the highly important Canadian Fisheries Expedition of 1915 and its ramifications for Canadian marine sciences should consult Johnstone (1977) and Hubbard (1993) among others. The voluminous (527 pages) report of the Canadian Fisheries Expedition (Hjort 1919), according to EE Prince, was rated at that time by "a leading American authority as the most valuable piece of marine and fisheries work accomplished in North America" (Hubbard 1993).

When Hjort returned to Canada in 1915 he actually came with two objectives. The first was to lead the Canadian Fisheries Expedition and the second was to introduce a patented method for quick-freezing fish. He had noted in the previous year the inferior quality of the Canadian 'fresh' and 'frozen' fish that resulted in low prices on the international and domestic markets and had commented, "That the excellent Atlantic salmon, the haddock and other fishes are salted" indicated "more than anything else the difficult position of the industry" (Hubbard 1993). Hjort had also observed that the practices in the herring fishery employing fixed gear caught coastal, mature, inferior herring rather than fat herring as caught offshore in Norway by using drift nets and purse seines.

As partial fulfillment of his second objective, Hjort wished to ensure that the Canadian Fisheries Expedition be conducted in the "closest possible touch with the industry and give practical results" (Hubbard 1993). To that end he recommended that fish freezing experiments be conducted in tandem with the Expedition. Accordingly, he carried out a demonstration of the Ottesen patent method for freezing fish which was stated to be "the only method of freezing which is cheap, rapid and perfectly preserves all the best food qualities of fish" (Hubbard, 1993). The demonstration consisted of freezing large fish in a barrel full of brine and ice at $-13 \mathrm{~F}(-25 \mathrm{C})$ in twenty to forty minutes i.e. approximately one third the time required with the airfreezing methods then in common practice. The results impressed everyone: fishermen, merchants and scientists and especially AG Huntsman. Unfortunately, with Canada now at war the cost of adding widespread demonstrations of freezing techniques to the overall expedition appeared prohibitive and that part of Hjort's proposal was turned down.

The lesson learned from Hjort, however, was not forgotten i.e. much greater economic returns could be realized by paying attention to production methods that enhanced product quality. Fish handling experiments were initiated by the Biological Board in 1915 especially to standardize curing methods using perfectly fresh fish. Despite equivocal results, Huntsman had these experiments repeated in 1917 with some improvements noted. The need for this kind of study in World War I was underscored by the complaints coming from overseas from both Canadian and British troops that the Canadian fish rations prepared from frozen Canadian fish were uneatable, tough and tasteless.

Prior to opening of the Atlantic Fisheries Experimental Station in 1925 the Biological Board of Canada did not have the facilities or mandate to carry out intensive research into fish processing. Individual members, however, influenced by Hjort and recognizing the paramount needs, did put 
increased effort into applied work to improve the fisheries and products. Without tracing out all the lines that eventually culminated in the technological programs it is clear that the various complaints about quality, the low prices and the recognition that matters did not have to remain this way, led to action in 1924. Unfortunately, as pointed out by Hubbard (1993), although the Department of Marine and Fisheries, convinced of the necessity, placed the Biological Board of Canada at the forefront of its actions to aid industry, the Department never had the funding to implement the extensive measures the fisheries needed. The result as noted by Stewart Bates in 1944, was that little in the way of modernization and industrialization had occurred in the Canadian Atlantic fishing industry to that date (Hubbard 1993).

In contrast with fisheries, American agricultural food industries, followed by those in Canada, extended careful grading to ensure freshness and quality, improved packaging, increased advertising to build consumer preferences and also generally improved methods of production, processing and marketing. In fisheries, the most notable change in the periods between World War I and World War II was the slow change away from salted fish to the fresh and frozen products (Hubbard 1993).

\section{The Technological Program}

In 1923, the Biological Board of Canada [re-named the Fisheries Research Board of Canada (FRBC) in 1937] was re-organized to accomplish a number of ventures including investigation of the technological problems of the fishing industry. A sum of $\$ 70,000$ had been voted to finance the development of two new technological stations, one at Halifax, Nova Scotia and the other at Prince Rupert, BC (later moved to Vancouver); this would aid the Board in fulfilling its expanded responsibilities in education work in connection with fisheries. Ultimately these two stations would be joined by another station at Grande Rivière, Québec, and Technological Units at London, Ontario (later moved to Winnipeg, Manitoba) and St John's, Newfoundland.

The station to be located in Halifax at the King's Wharf, named the Atlantic Fisheries Experimental Station (AFES), was housed initially in some vacant federal buildings that were refitted during 1924 to accommodate the work (Fig 1). A subcommittee on education appointed by the Biological Board of Canada met in March 1924 to consider the educational work in fisheries and made the following recommendations:

1) That a Director be appointed at the earliest possible date to initiate and carry out educational work.

2) That the said Director procure information on the technology processes of fisheries as a preliminary step to conducting a scheme for educational work. 

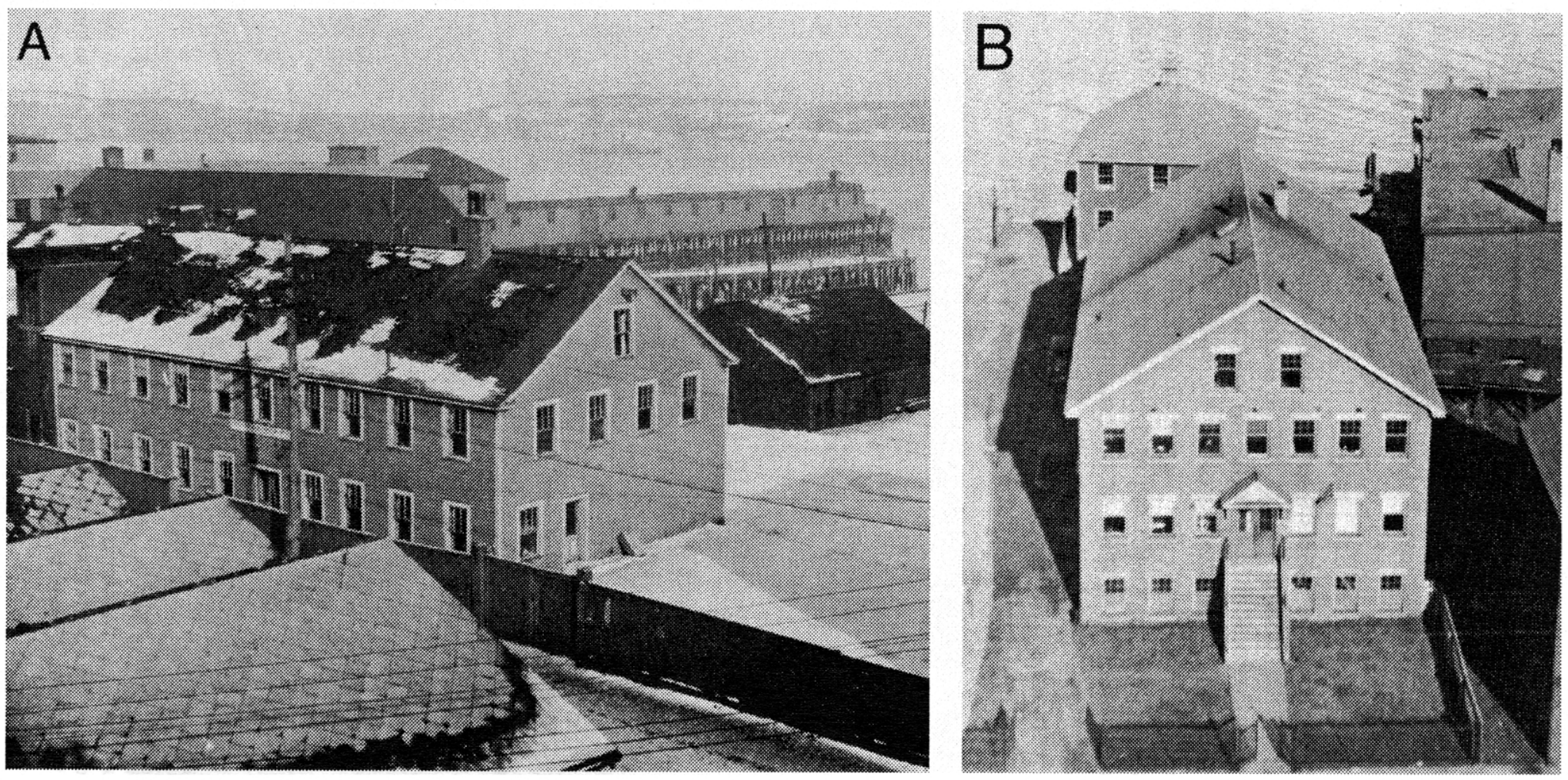

Fig 1. The temporary building occupied in 1925 by the Atlantic Fisheries Experimental Station, 1721 Lower Water Street, Halifax (labeled "A") and the purpose built structure at 1707 Lower Water Street (labeled "B") occupied in 1930. 
3) That there be prepared as regularly as possible pamphlets for issue on matters of educational interest and in connection with the work of the Biological Board.

4) That the said Director plan the equipment of the Station so that it may be used for demonstrating fishery methods and processes" (Johnstone 1977).

After considering all applicants for the directorship it was decided to request $A G$ Huntsman to take the post while also retaining the directorship of the St Andrews Biological Station as he was regarded as a 'glutton for work' and had been influenced greatly by Hjort and Knight (a senior Biological Board member) on the value of applied science (Johnstone 1977). He accepted this appointment and directed studies through to 1928, and in fact continued some studies on processing after his return to full-time duties at St. Andrews. The building at the King's Wharf was ready by the spring of 1925 [replaced by a purpose-built laboratory next door in 1930-31 (see Fig 1, 2)]. The first investigations undertaken dealt with the smoking of fish.

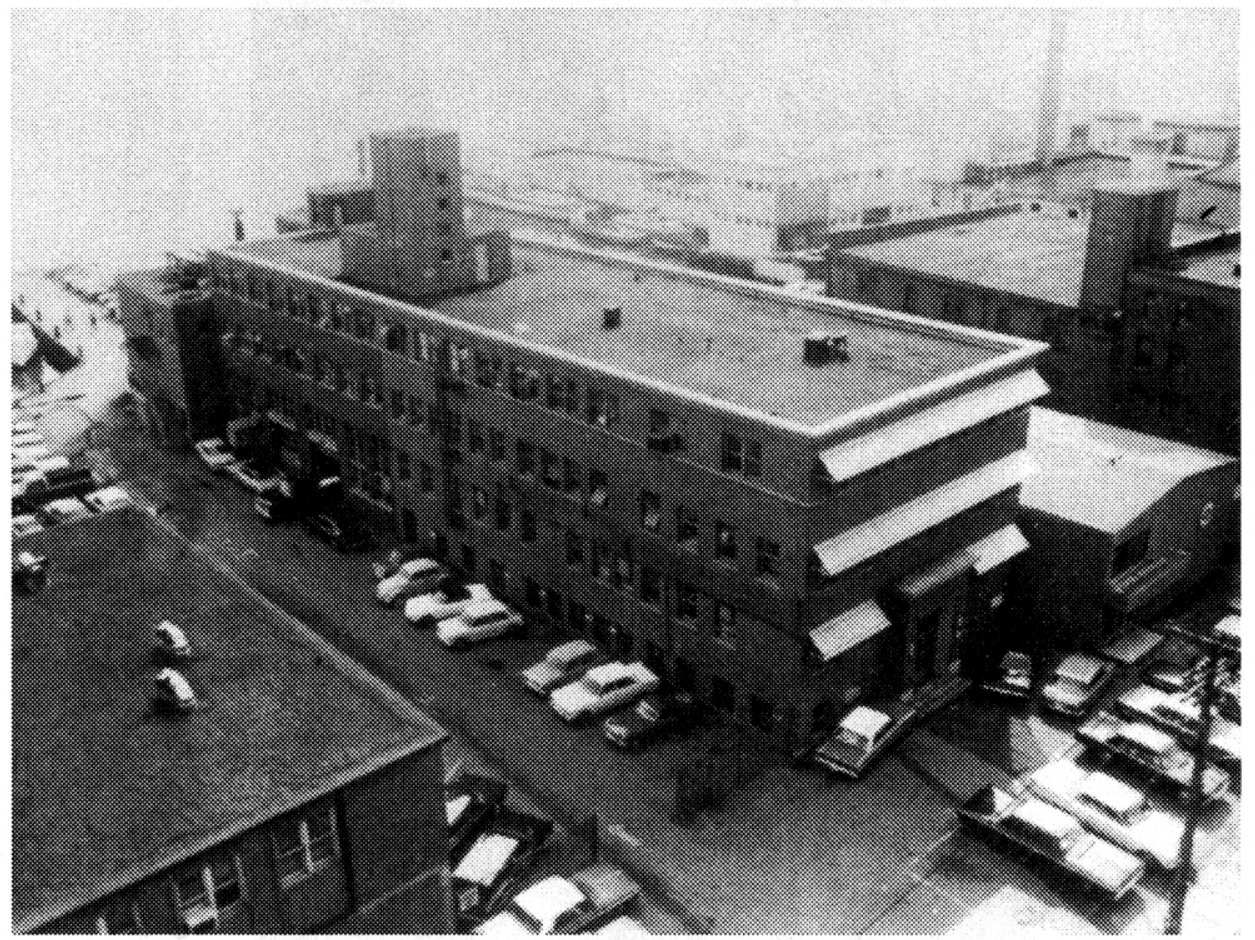

Fig 2. The much modified final form of the building at 1707 Lower Water Street in the 1970s (by then known as the Halifax Fisheries Research Board Laboratory). At its peak in the 1960s it provided facilities for around 90 staff. 


\section{Smoked Fish and Salt Fish Innovations}

The smokehouses of the day were devoid of environmental controls and therefore it was not uncommon for the fish to either dry out or cook while being processed. Research showed that the best tasting "finnan haddies" were smoked after the fish had passed through the stage of rigor mortis, and that a light smoking produced the best results.

In 1937, AFES engineers developed a prototype mechanical smokehouse which became the standard for the Atlantic fish industry. In addition to ensuring quality control, it reduced smoking time from 15 hours to 7 hours. A further improvement in the design dropped that to three hours, enabling the production of 400 pounds of smoked cod fillets per hour.

As the foggy and humid weather conditions in Newfoundland were not conducive to salt fish drying, some of the salt fish shipped to the major Caribbean salt fish markets arrived mouldy. Scientists and engineers at the Halifax Laboratory applied yet another mechanical solution. The mechanical salt fish dryer they developed was the first in Canada, and is believed to have been among the first in the world. "It meant the salvation of the salt fish industry in the Maritimes," recalls Dr. Graham Bligh, the last Director of the Halifax Laboratory. As well, the AFES engineers made major improvements in applying refrigeration i.e. insulated fish holds, the incorporation of refrigeration in railway cars, and refrigerated live lobster holding units for retail outlets.

\section{Frozen Fish}

Perhaps the Halifax Laboratory's most striking claim to fame was the production of the world's first commercial-scale frozen fish in 1929. More than 16,000 pounds of "Ice Fillets" produced between April 1, 1929 and March 30, 1930 were shipped to Toronto for sale. They were called "Ice Fillets" because "frozen fish" connoted an inferior product in those days. The merits of the approach can be gauged by the fact that the Ice Fillets commanded a price 50 percent higher than "fresh fillets" of haddock kept on ice. In the words of one Toronto hotel manager, "The quality of this fish covering all kinds sent was perfect. The meat was firm, the juices were intact, in fact we in this country have never tasted such perfect fish as what you shipped to us" (Hubbard 1993).

In order to prevent fish from drying out while in cold storage, it became necessary to maintain humidity in the cold storage room. To this end, the first "jacketed cold storage room" was built at the AFES in 1927. This was accomplished by surrounding an experimental cold storage room with a jacket of circulating air which prevented the moisture of the fish from migrating to the refrigeration coils. This system proved to be particularly useful on the West coast where unpackaged fish was placed directly into freezer holds. Further enhancements to the jacketed cold storage system were made at the FRB Atlantic Biological Station in St. Andrews, New 
Brunswick and at the FRB Fisheries Experimental Station in Prince Rupert, British Columbia.

The AFES also received world-wide recognition for its noteworthy contributions made over the years in the area of frozen fish including the importance of rapid freezing, low temperature storage, the detrimental effects of fluctuating storage temperatures, the biochemical and physical changes continuing in the proteins and fats in the fish during frozen storage and various tests for evaluating the quality of frozen products (e.g. protein solubility tests and measuring increases in free fatty acid values).

\section{Fish Protein Concentrate and Minced Fish Products}

During the 1960s the FRB Halifax Laboratory played a significant role in the development of Fish Protein Concentrate (FPC or fish flour), the technology that was to convert underutilized fish and edible fish wastes into a super protein to nourish the starving people of the world. Although a superior product was produced, FPC never gained commercial acceptance and the Halifax Laboratory went on to develop technology related to minced fish. Research showed that minced (or de-boned) fish tissue deteriorated more rapidly than intact muscle due to the release of enzymes and the incorporation of air. Nevertheless, minced fish technology advanced quickly here and elsewhere and now is utilized in producing a variety of valueadded products including artificial crab legs (surimi) etc.

\section{Fish Oils and Fatty Acids}

\section{Lipid extraction methodology}

From the Halifax Laboratory's focus on reducing fish spoilage, several breakthroughs of international interest evolved in the area of fish oils and fatty acids. In order to monitor the biochemical processes that take place in frozen fish, it became necessary to extract the lipids at various intervals to determine at what point deterioration took place. Existing methods were not only laborious, but they were also destructive, and so in 1959 a method employing chloroform and methanol was devised which produced highquality lipid extractions from wet fish tissue within minutes. The process, recognized as a "Citation Classic" is still employed worldwide in the analysis of lipids from a variety of plants and animals.

With regard to the original intent - to investigate the causes of lipid breakdown during the frozen storage of lean fish - the scientists identified the enzymes that were responsible for the release of fatty acids. Their recommendation to preserve the integrity of the lipids included maintaining a temperature low enough to slow the actions of the enzymes responsible for denaturation. 


\section{Fatty acid compositions: analysis}

The advent of gas liquid chromatography in the mid-1950s precipitated a revolution in the field of fish oil analysis. An analysis that used to take three to four months could now be completed in an hour, and scientists were suddenly able to identify the fatty acids in fish oils rapidly and to trace changes in them. Scientists identified the particular fatty acid compositions of different fish oils, such as herring and capelin oils, enabling them to be used industrially in varnish and paints. Although in these products fish oils were displaced by polyvinyls in the 1960 s, fish oils continued to be used in margarine and shortenings until they were replaced by 100 per cent vegetable oil.

From 1965 to 1970 , the medical community began to preach the merits of fish as excellent sources of polyunsaturated fatty acids - just what the doctors were prescribing for the heart. At that time, the Halifax Laboratory provided companies such as Connors Brothers and National Sea Products with information about fatty acids which could then be supplied to nutritionists and dietitians.

In 1975, the Danish government dispatched two biochemists and a team of medical specialists to Greenland to study why the Inuit only rarely died of heart disease. They concluded that the Inuit ate seals, which have a fat with fatty acids similar to fish oils, and that certain long chain fatty acids unsaturated in the omega-3 position, were particularly healthful. Analyses by experts in fish oil compositions at the Halifax Laboratory provided the basis for some of these studies. When the technology branch was dissolved in the late 1970s, the fish oils section relocated to the Canadian Institute of Fisheries Technology at the Technical University of Nova Scotia, where the work related to this theory was completed.

During World War II, rapeseed, which contains a long chain fatty acid, had been used as a lubricant for steam engines. With the financial support of the Department of Agriculture, a new rapeseed cultivar was developed that produced both low erucic acid and glucosinolate levels. Between 1970 and 1975, studies at the Halifax Laboratory on the elimination of the undesirable erucic acid content in rapeseed oil contributed significantly to the development of the world's first canola oil, which now accounts for 95 percent of the edible oil used in Canada.

While some of the scientists working in the area of fish oils focused on defining fatty acid compositions, still others were advancing scientific knowledge in the area of oxidative rancidity in the storage of frozen fish. The high content of unsaturated lipids in fish promotes rapid oxidation, and it was discovered that fish oils exposed to metals oxidized even faster. Scientists at the AFES also found that blood products catalyze rancidity, and that washing the blood from fish tissues protected the product from the development of rancidity.

In addition, much of this work on the marine oils provided the basic information that led to subsequent commercial exploitation of the various components. A number of the commercial products now being produced locally arose largely as a result of this work. 


\section{Fish Spoilage and Grading}

At the same time, as the marine oils work proceeded, chemists and bacteriologists focused on the other factors contributing to the rapid spoilage of fresh fish. The importance of good sanitation and the prevention of bacterial contamination were stressed. Procedures for the proper handling and icing of fresh fish and fillets were recommended to industry along with methods for salting, smoking and canning of fishery products. In all of these studies, the emphasis was on the fundamental aspects of fish as food. To this end the scientific studies focused on the proximate concentration in terms of fats, proteins, carbohydrates, nucleotides, nucleosides, purines, pyrimidines etc., followed by basic studies on their stability under varying temperatures and conditions. Not only were the changes in triglycerides/individual fatty acids and protein denaturation followed, but the agents of change (spoilage) i.e. fish enzymes, bacteria and chemical factors were identified and means were devised to prevent the changes. In addition, once the chemistry of the changes was revealed the various products of change could then be used as indices of quality to assign specific grades denoting fish quality, thus allowing grading to be based on highly objective analytical tests instead of the rather imprecise organoleptic testing then in use. The development of grading techniques and tests for quality (è.g. the trimethylamine test, hypoxanthine etc.) were important advances which together with other technological information, formed the foundation for fish inspection regulations. This information was used to develop fish inspection systems, which were then used to train staff and to found a Fisheries Inspection Service. This information was provided also to the industry through formal training programs, workshops and the distribution of printed "Circulars" and the Atlantic Progress Reports. Several long-term studies were aimed at inhibiting bacterial spoilage and included the use of antibiotics, gamma irradiation and super-chilling.

Until the 1960s studies at the Halifax FRB were concerned primarily with improvements in preventing deterioration of catches of fish and fisheries products from the point of harvest at sea through to delivery to the consumer. The goal was to determine and introduce procedures and practices that would achieve this through grading systems to measure and assign quality designations for the fresh or frozen products.

Gradually as studies devoted to product quality gained ground, it also became apparent that quality was not solely a function of post-mortem changes wrought by resident enzymes and bacteria associated with the fish (skins and viscera). The quality of the fisheries products was also influenced to a large degree by the stage of their life or annual cycles that the fish or shellfish were in prior to capture. 


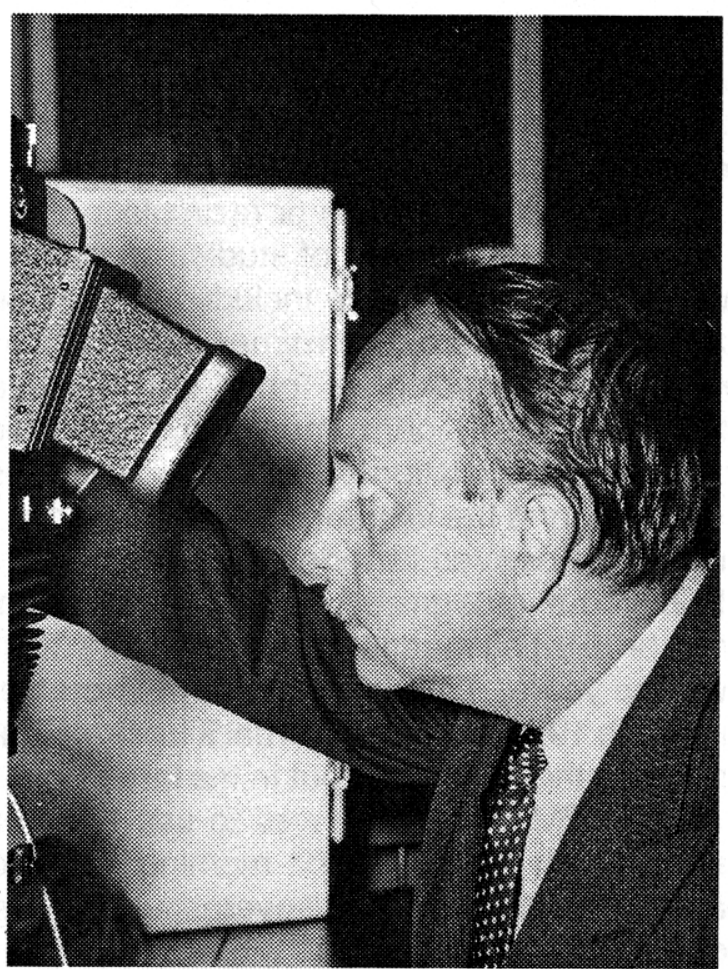

Fig 3. Charles $\mathrm{H}$ Castell, teacher, extension worker and scientist as described in one citation: "He has almost single handedly substantially improved the industrial practices concerned with fresh fish and in so doing added materially to the income of the Atlantic Fisheries industry ... His more outstanding achievements stemmed directly from his ability to communicate with all levels of people from top to bottom in the fishing industry and in government circles. He managed to put across a system of voluntary grading and later a Federal Fisheries Service grading and inspection system which was effective because he had worked hard to make it acceptable to both sides. The system itself was based upon Mr. Castell's research work which he managed to conduct while doing the field work on the fresh fish industrial practices ..."

\section{Live Animals Added To The Laboratory Focus}

Accordingly, more and more effort was directed to studying the condition of the live fish and shellfish and integrating this information into the studies which had preceded them to give a more comprehensive approach to ensuring quality products. In addition, problems of varying degrees of complexity arose in which live animals figured more prominently and required additional techniques and approaches. Many of these studies arose from the continuing needs of the harvesting/processing part of the fisheries while others originated with requests from the allied Biological Stations of the Fisheries Research Board. The interests of the new director, Dr David Idler, and enhanced resources added impetus to this enlarged perspective. From his work as a scientist at the Vancouver Station on the chemistry and biological function of hormones in the extended migrations of the Pacific salmon species, Dr Idler retained an interest in live animal studies. He was especially interested in applying these techniques and 
findings to Atlantic salmon. At the beginning of his term in office a full-scale fresh and salt water working aquarium was built. Equipped with sources of good quality water, a system of large, intermediate and small tank units was supplied with seawater or freshwater maintained at various temperatures; these could be operated on either open or recirculating water systems.

From 1962 onward, a wide variety of studies on live animals (both fish and shellfish) were carried out. These included studies on the chemistry and physiological function of steroid hormones especially in Atlantic salmon and skates, detection of physiological forms of antifreeze in cold water species, digestive enzymes, isoenzymes/starch gel electrophoresis to discriminate between populations, histology, diseases, nutrition, contaminant absorption, and the influence of hydrocarbons on animals and thus on the quality of the derived fisheries products.

As the FRB became recognized as an authority on marine life in general, fishermen brought all manner of exotic sea life to the Lower Water Street facility over the years. One of the more memorable examples was "Timothy the Turtle". In 1971, a live leatherback turtle weighing about 1,000 pounds was donated to the AFES and put in the large deep tank at the rear of the building at 4:00 PM. The plan was to use him in the marine oils program the next day. At 7:00 the next morning, news of "Timothy the Turtle" was broadcast live by radio and several hundred people flocked to the Halifax Laboratory to catch a glimpse (Fig 4).

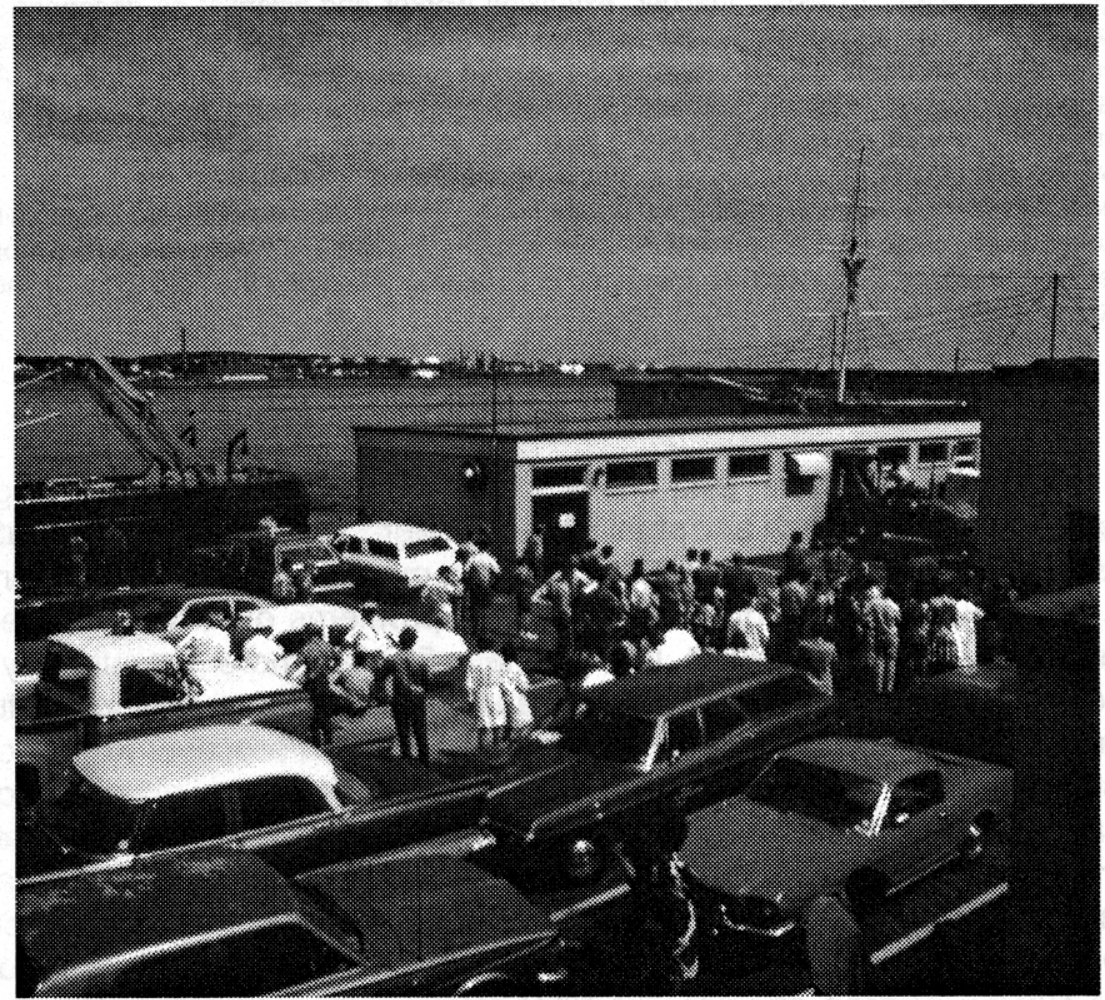

Fig 4. The crowd drawn in 1971 to the 1707 Lower Water Street rear tank building by the news of "Timothy the Turtle". 
As the crowds and the objections by various groups prevented any work taking place it was decided, after much discussion, to release him at sea. In order to take him out of the tank, part of the building had to be removed; a mobile crane then lifted him from the tank and hoisted him on board a fisheries research vessel and he was set free outside the harbour. As this was the first day on the job for the newly appointed director, Dr EG Bligh, his dismay, generated by these happenings, led to implementation of stringent rules as to what could and could not be accepted for studies at the Halifax FRB Laboratory (Fig 5).

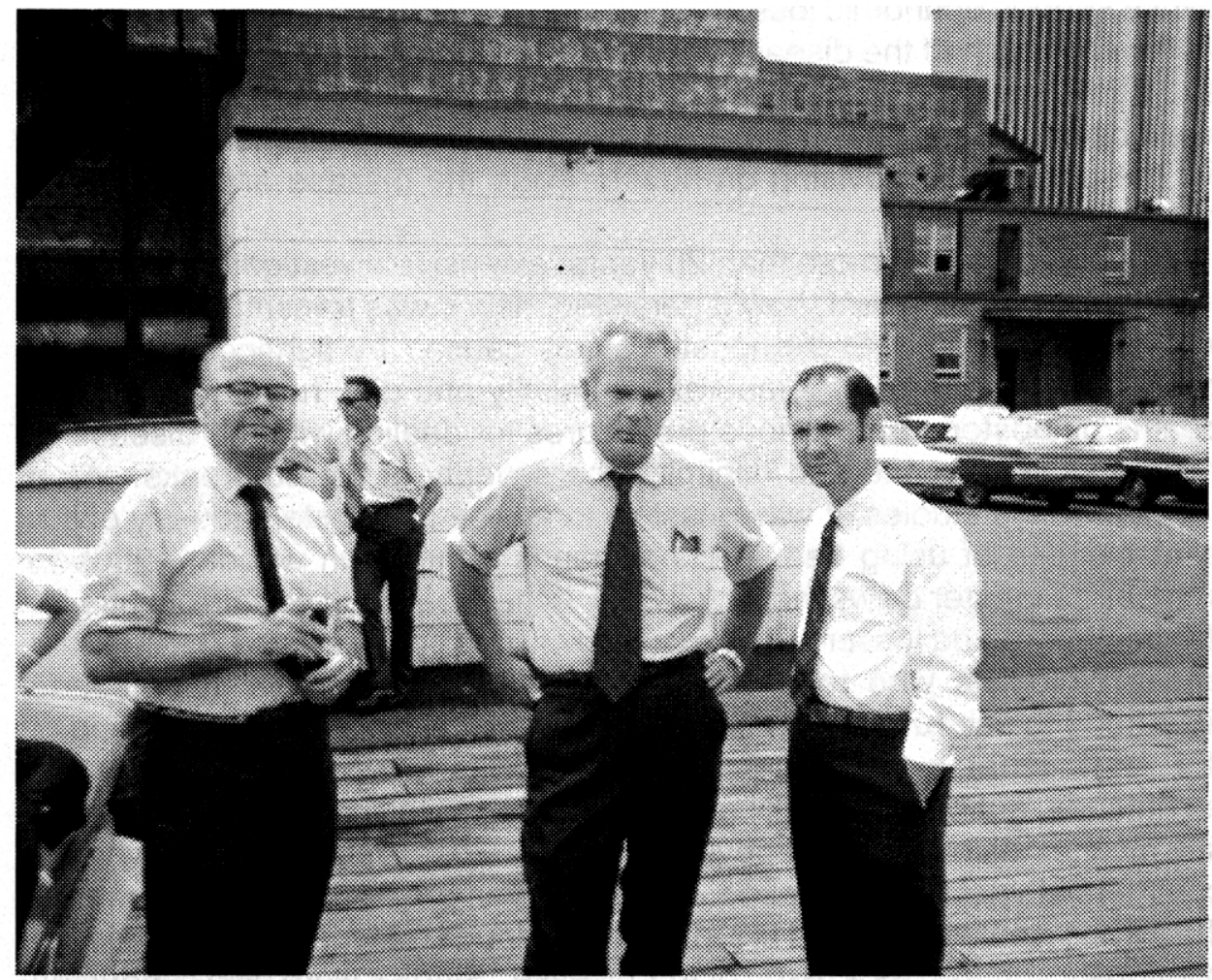

Fig 5. Viewing the activities related to "Timothy the Turtle". Left to right in the foreground $\mathrm{Dr}$ RG Ackman, the scientist in charge of the Marine Oils program, Mr David Horne a scientist from the Fisheries Inspection Service Laboratory, and Dr EG Bligh, the Director of the Halifax Fisheries Research Laboratory on his first day on the job. 


\section{Disease Studies}

\section{Lobsters and oysters}

Work on diseases began in the summer of 1961 when a major and widespread episode of a bacterial infection of lobsters occurred. This infection was caused by a bacterium originally named Gaffkya homari [now Aerococcus viridans (var.) homari], thereby giving rise to the disease name 'gaffkemia'. It had been discovered and described in 1947 in Maine. The causative agent is highly virulent and is a chronic threat to both wild lobsters and more importantly to lobsters held captive in holding units where it can cause serious economic losses i.e. as high as $10 \%$ of the lobsters/day. As little was known of the disease other than the identity of the infective agent and as the infection was a major threat to the highly important and profitable live lobster industry, the Halifax FRB Laboratory undertook intensive studies for the purpose of advising on how to avoid the disease and/or develop mitigative measures.

Over a period of more than 20 years, extensive investigations showed the sources of the agent, how it persisted, how it was transmitted (through wounds and breaks in the lobster shells caused by fighting and rough handling), the effects of temperature, salinity and diet, how it caused the deaths of lobsters, and various procedures for dealing with the disease to reduce its occurrence and minimize the severity of the outbreaks. As a result of these studies, it was possible to advise the lobster industry of the effectiveness of using heavy rubber bands rather than wooden plugs to immobilize lobster claws thereby reducing the creation of portals of entry for the bacterium and lessening infection rates. This advice was added to that of the biologists who had been attempting for some time to persuade fishermen to use rubber bands to eliminate shell erosion and blackening of the claw meat. Additional information was provided on diagnostic techniques, antibiotics, use of refrigeration, improved handling, holding and shipping conditions and the development of several vaccines upon which a commercial vaccine was based. These studies provided a number of tools that, when applied, allowed the industry to reduce materially the high losses previously suffered as a result of this disease. Studies were also conducted on a condition of lobsters known as shell disease. Shell disease in the early stages causes unsightly erosions of the shell and in later stages causes the death of the lobsters. Fortunately, neither of these infections affects humans.

In addition to the studies on lobster diseases, work was also begun on an infection of oysters that had destroyed many of the oyster populations in Prince Edward Island starting in 1913 and in New Brunswick and the Northumberland Strait part of Nova Scotia in the mid 1950s. This disease was called Malpeque Disease largely because Malpeque Bay was where the disease was first observed and where the studies were initiated. A great deal of work was done that proved to be helpful to the oyster industry, although it did not result in the identification of the disease causing agent, nor in the elimination of the disease. 


\section{Fish}

Gradually as more attempts to culture fish were made and more emphasis was placed on maintaining the health of fish in both government and private hatcheries, disease studies at the Halifax FRB Laboratory expanded. Understanding the conditions that led to disease among cultured fish also led to studies comparable to those carried out on shellfish. The already substantial aquarium facilities for live animal work were expanded to accommodate disease studies on both fresh and saltwater species. Thus, increased physical facilities and most importantly a significant increase in well trained and experienced staff allowed fundamental and comprehensive studies on diseases of cultured fish to be undertaken. These were focused on diseases caused by Infectious Pancreatic Necrosis Virus (IPNV), the bacterium Aeromonas salmonicida (furunculosis) and Renibacterium salmonarum [Bacterial Kidney Disease (BKD)]. In addition to diagnostic studies and field surveys, work was instituted on studies on the modes of pathogenicity of these agents, the means to control them and vaccines to prevent the infections in the first place.

\section{Fish Health Unit}

The increasing awareness of aquatic animal diseases in the hatchery systems, fish kills in the wild and in various aquaculture ventures led to requests to diagnose and deal with on-site problems. At first individual scientists dealt with these on an ad hoc basis. As the workload continued to increase it became obvious that a better solution was needed.

Working collaboratively with other scientists across Canada, Halifax FRB staff helped to develop the Fish Health Protection Regulations (FHPR) which were set up to control the inter-provincial movement of salmonid fish coming from sources known to harbour specifically-listed pathogens. This was to prevent the spread of fish diseases from one province to another. A Fish Health Unit was then set up at the Halifax FRB Laboratory to carry out the mandate of the FHPR in the Maritimes. This was a diagnostic unit that certified establishments that wished to export cultured fish or eggs of wild fish. Certification was only given to facilities that could be shown to be free of certain named diseases. For example, salmonids could be imported into Nova Scotia from British Columbia only from facilities that were certified as being free from Infectious Hematopoietic Necrosis Virus (IHN).

The Fish Health Unit was a leader in this field and some of the diagnostic techniques introduced at the Halifax Unit were emulated elsewhere. For example, a stress test that this Unit adapted for improved detection of furunculosis in carrier fish was, in turn, adopted and used by the New Brunswick Department of Aquaculture Diagnostic Laboratory. 


\section{Aquaculture Pushes Nutrition Development}

The need to understand the dietary requirements of lobsters held captive for varying periods in the lobster trade and the need to improve the diets of farmed fish led to the initiation of nutritional work in 1970. The Aquaculture Section became renowned for its expertise in crustacean nutrition - both in terms of defining nutrient requirements and formulating and producing feeds for both the fishery and the aquaculture industry. While the work was focused principally on the American lobster, the nutritional needs of spiny lobster, freshwater crayfish, and 12 species of penaeid shrimp were also considered. Scientists at the Halifax FRB Laboratory developed standardized methodologies for fish and crustacean nutrition research, and were instrumental in founding the International Working Group on Crustacean Nutrition. In collaborative studies diets formulated at the Halifax FRB Laboratory were tested against more than 30 species of crustaceans in many countries including Japan, Ecuador, France, Tahiti, the United States, Germany, and Sweden.

These studies were extended in 1976 to develop new diets for use in salmon hatcheries. The objective was to improve the rate of return of salmon smolts used in the enhancement programs. Scientists working in the Halifax FRB Laboratory were responsible for kick starting the development of diets for Atlantic salmon in full culture conditions. The salmon feeds that were developed in-house satisfied the dietary requirements of the salmonids and resulted in eliminating a variety of problems. Through a successful technology transfer program, the Halifax Fisheries Laboratory's formulation was produced by private sector feed makers. To a considerable degree, New Brunswick's lucrative cultured salmon industry and that developed in other parts of the world owes much of its success to the work that came out of these studies.

In another application of nutrition research, scientists in the Aquaculture Section developed and supplied a vitamin concentrate pellet for halibut and haddock broodstock. This became necessary because these fish, which had been captured in the wild, did not thrive on the standard dry pellet feeds. The pellet produced as a result of these studies ensured that the eggs would not be deficient in essential vitamins and minerals.

\section{Histology}

Utilizing light and electron microscopy, including at one stage one of the first scanning electron microscopes in Canada, scientists working at the Halifax FRB Laboratory studied the musculature and other organ systems of cod, scallop, lobster, oyster and commercially important fish in order to provide a baseline for product quality considerations, nutritional studies as well as comparisons between normal and diseased specimens. Members of this group also wrote four atlases on cod histology used by many scientists working on cod and related species in Canada, Norway and the United States. 


\section{Contaminants}

From time to time various problems arose for fisheries as a direct result of industrial activities. There were numerous instances of these and all required chemical and/or physiological studies for assessment, detection and/or amelioration. A partial listing would include acid rain, marine algal toxins i.e. domoic acid and Paralytic Shellfish Poisons in shellfish, metals e.g. cadmium and mercury contaminating fisheries products as well as the hazards of materials such as chlorinated hydrocarbons in the marine environment. From among those that arrived at the door of the Halifax FRB Laboratory, two will be sufficient to illustrate the nature of the problems experienced.

\section{Phosphorus}

In February 1969, massive concentrations of dead herring were reported piling up on beaches in Placentia Bay in southern Newfoundland. These were described as "red herring" and were being washed ashore to form large windrows; the different occurrences proceeded in an anticlockwise direction around Placentia Bay. This crisis generated an enormous amount of work on the part of FRB scientists in Newfoundland, Nova Scotia and New Brunswick. As a result it was determined that the massive kill of herring was caused as a result of the fish, on their annual spawning migration, swimming through a plume of colloidal elemental phosphorus from a new commercial producer. The fish, depending upon their position in the school, absorbed varying concentrations of the phosphorus. The high concentrations gave rise to petechial bleeding, hence the red coloration and the designation "red herring". As the migration proceeded, the fish which had absorbed the highest concentrations died first followed by those with lesser concentrations. Thus the dead fish washing ashore in huge concentrations traced out the course of their annual spawning migration around Placentia Bay. Thus began a crisis of some eight months duration that consumed a large proportion of the time of FRB scientists, particularly at the Halifax Fisheries Laboratory where much of the analytical work, toxicology studies and direction of the crisis activities took place.

The plume of colloidal phosphorous was coming from Long Harbour where a huge electric reduction plant had begun distilling phosphorus from fluorapatite ore mined in Florida. The distilled phosphorus was condensed and stored under water thereby displacing the water in the condensing tanks. This displaced water was released continuously into Long Harbour and gradually moved through the Harbour out into Placentia Bay. Although most of the elemental phosphorus sank to the bottom of the condensing tanks, the finely divided material (colloid) remained in suspension and was released with the displaced water and provided the toxic effects of the plume.

As the episode had destroyed the herring run and posed a threat to all fisheries in the Bay as well as consumers, the fisheries for all species were 
terminated and the phosphorus plant was shut down at once. As a direct result, hundreds of fishermen as well as the employees at the phosphorus plant were thrown out of work. This pollution episode is still the largest and most devastating anthropogenically produced, marine acute toxicity event experienced to date in Atlantic Canada.

Eventually the problem was resolved through a mixture of highly original chemistry, toxicology, clean up, pollution control and expensive compensation programs. Regardless, the conclusion was that if reasonable and informed technical foresight had been applied initially the crisis could have been avoided completely (for the complete story see Jangaard 1972).

\section{Oil spill}

The second contaminant issue resulted from the wreck in 1970 of the 'Arrow', a small tanker carrying Bunker C, a heavy fuel oil petroleum fraction. As a result, Chedabucto Bay was badly fouled. The threat to fisheries, fish processing plants and fish quality was considered serious and pressing. Scientists from the Bedford Institute and the Fisheries Research Board were called upon to aid in the declared emergency. Two immediate and basic questions were: what would be the long-term consequences and would the area cleanse itself given time? Studies conducted by Halifax FRB staff showed that hydrocarbon-utilizing microorganisms were plentiful in the area, that their rate of action was governed by temperature and the availability of key nutrients, nitrogen and phosphorus and that the bacteria were capable of cleansing most areas given time. In the meantime, under the direction of the Department of Transport, key areas were cleaned by hand and mechanically; the bulk of the oiled areas was left to clean up through natural processes.

\section{THE FISHERIES RESOURCE BRANCH PROGRAM}

Following the termination of the Technological Branch programs in 1978, those elements that remained in the Halifax Fisheries Research Laboratory were already part or became part of the Fisheries Resource Branch responsibilities. The continuing activities of the scientists and sections originally part of the Technological Program have been covered within the first section to avoid confusion.

In the mid 1980s the Invertebrates and Marine Plants Division, previously without laboratory space, moved to the Halifax Fisheries Research Laboratory. They were joined there by elements of the Freshwater and Anadromous Division and some contractors. The remainder of this retrospective covers their sojourn.

The Halifax Fisheries Research Laboratory, as a consequence, became home to several applied research projects which provided scientific advice for the management of economically and socially important invertebrate fisheries: lobster, scallop, shrimp, offshore clams etc, and also marine plants. For example, the successful offshore scallop industry, in particular, 
prospered under an Enterprise Allocation system based on knowledge and advice generated by Fisheries Resource Branch scientists.

\section{Harvest Fisheries}

The Marine Plants Unit assisted in helping both government and the private sector to assess and manage coastal varieties of seaweeds including Irish moss, rockweed, wire weed and kelp. Remote sensing techniques, including multispectral airborne and satellite-based sensors, were applied bringing these techniques into common usage for the determination of algal standing crops. As a result, Furcellaria is now being harvested in western Prince Edward Island, currently yielding up to 700 metric tonnes per year at a value of $\$ 800$ per tonne. An extract of this marine plant is used as a gelling and emulsifying agent in foodstuffs. In addition, the Unit has developed techniques for rapidly sampling seaweeds and associated organisms, thereby assisting in gaining an understanding as to how the removal of seaweed impacts invertebrates in the ecosystem.

In the early 1980s, staff mapped the occurrence of a disease that killed 270,000 tons of sea urchins along $360 \mathrm{~km}$ of the outer coast of Nova Scotia. This sea urchin mortality level, however, heralded a renaissance of the kelp, which grew an additional five million tons per year. In addition, the urchins now no longer interfered with the lobster fishery. By the mid-1990s the urchins had recovered and in a reversal of fisheries interests now supported a lucrative diving fishery, a valuable export industry and renewal of interest in urchin culture by the aquaculture community. Staff was also instrumental in introducing property rights to the sea urchin fishery. In exchange for fishing rights, fishers were required to apply harvesting approaches that were designed to enhance urchin productivity.

Turning underutilized species into harvestable resources is always a worthy challenge, particularly when the seafood in question appears in significant volumes. Because small boats could not use trawl-harvesting methods, pink shrimp were in this underutilized category. The.Molluscan Fisheries and Aquaculture Section worked with industry to develop a trap that would enable as few as two fishers to harvest shrimp from a small lobster boat; nine fishers are currently licensed, and six more are scheduled. Using these low operating cost boats, they are averaging five to six pounds per trap and some have 100 traps per license. It is proving to be a lucrative fishery.

\section{Parasitology}

Parasitologists at the Halifax Fisheries Laboratory advanced scientific knowledge with regard to seal worms and other parasitic nematodes which grow in the flesh and viscera of marine fish as larvae and mature in the gastrointestinal tract of marine mammals. The research concluded that seal 
worms affect more than three dozen species of marine and anadromous fish in eastern Canada including mature Atlantic cod, cusk, monkfish and sea raven. Benthic crustaceans such as mysids and amphipods are important transmitters of the larval seal worm to fish. Not surprisingly, the heaviest infections have been found in fish caught near Sable Island, where the expanding populations of the definitive host, the grey seal, forms its largest breeding concentrations.

As well, scientists at the Halifax Fisheries Research Laboratory published many studies on protozoan parasites of finfish with the demand for more information increasing with the rise in aquaculture. These parasites can multiply more easily in fish farming operations than in the wild. A group of microspora (Loma sp.) was recognized and named by Halifax Fisheries Research Laboratory scientists working in conjunction with scientists in the US. This parasite has caused mass mortalities in salmon and trout in Alaska, Scotland and elsewhere, and is causing mortalities of a less severe nature among cultured salmon on the west coast of Canada.

\section{Acid Rain}

From the late 1980s until 1997, the Freshwater and Anadromous Division studied the effects of acid rain on salmonids and invertebrates living in rivers and streambeds in Nova Scotia. Low survivability of salmonid eggs occurred under acid rain conditions; unfortunately most invertebrates in the ecosystem, which serve as an essential food source, were similarly impacted. As a result a number of rivers on the Atlantic coast of mainland Nova Scotia have lost their resident populations of Atlantic salmon.

\section{ACCOLADES}

On a number of occasions scientists at the Halifax Fisheries Research Laboratory have been singled out for awards for published studies, personal communications and transfer of information and techniques to fisheries and allied interests. A number of these are listed below:

Charles H Castell

Centennial Medal 1967

Earl McFee Memorial Award 1971, Atlantic Fisheries Technological Conference

Public Service Commission Merit Award 1971

Nova Scotian Environmental Award 1985 (Research on Acid Rain)

\section{William J Dyer}

Awards from:

United Nations Food and Agriculture Organization 
Canadian Institute of Food Science and Technology

Chemical Institute of Canada

Japanese Society of Fisheries

Japanese Society of Heating, Refrigeration and Air Conditioning

Engineers

\section{E Graham Bligh and William J Dyer}

Citation Classic Award for:

A rapid method of total lipid extraction and purification. Can $\mathrm{J}$

Biochem Physiol (1959) 37:911-917

\section{Robert G Ackman}

Public Service Commission Merit Award 1979

Member of the Order of Canada 2002

LLD (Hon), Dalhousie University 2003

\section{CONCLUDING REMARKS}

It is appropriate that this retrospective appear in the Proceedings of the Nova Scotian Institute of Science, since the Halifax FRB Laboratory and the Institute have enjoyed a close association over the years. Many of the scientists who worked at the Halifax Fisheries Research Laboratory have been members of the Institute, have served on its committees and its Board. The following served as NSIS President: E Hess (1942/43), JR Dingle (1959/60) WJ Dyer (1966/67), RG Ackman (1973/74), PH Odense (1978/79), EG Bligh (1987/88), and JE Stewart (1992-94).

In closing this account it should be stated that the reasons for terminating the Technology Program across Canada included the understanding that the fisheries industry, while gaining much from the program, had now matured and was in a position to look after its own technological needs. It was considered that the industry could do the necessary work in-house or failing that could contract with experimental entities such as the Canadian Institute of Fisheries Technology begun at the Technical University of Nova Scotia (now the Engineering Faculty of Dalhousie University) with transferees from the terminated Fisheries Technology Program. As the buildings at 1707 Lower Water Street had reached the end of their useful lives, they were demolished as soon as alternative accommodation was found to re-locate the remaining activities.

This retrospective has touched upon many of the activities that took place in the Halifax Laboratory and briefly described a number of them. It should also be emphasized that the Halifax Fisheries Research Laboratory had an active educational role. In addition to the transfer of its findings to industry and other agencies already described, it played host to a lengthy list of visiting scientists, post doctoral fellows, graduate students and summer students. Many staff members taught or participated in courses offered at post secondary institutions in and around Halifax. As many of 
those visiting or working in the Halifax Laboratory came from other parts of Canada and other countries the sharing of information and scientific cooperation was accelerated greatly and was an extremely important and valuable aspect of the Halifax Laboratory's activities.

The final appraisal of its accomplishments, however, should be left to independent assessors. One, in referring to certain of its activities gave what could serve as a fitting epitaph: "The scientists running the Halifax Fisheries Experimental Station tended to respond positively to requests for these initiatives: fish-processing, research and educational work were probably the greatest contributions to the Atlantic Fisheries made by the Biological Board in the interwar period" (Hubbard 1993).

\section{REFERENCES}

Graham M (1943) The fish gate. Faber \& Faber, London

Hjort J (1914) Fluctuations in the great fisheries of northern Europe viewed in the light of biological research. Rapp P-V Réun Cons int Explor Mer 20:1-228

Hjort J (1919) Canadian fisheries expedition 1914-1915: investigations in the Gulf of St. Lawrence and Atlantic waters of Canada. King's Printer, Ottawa

Hubbard JM (1993) An independent progress: the development of marine biology on the Atlanric coast of Canada 1898-1939. PhD thesis, University of Toronto

Jangaard PM (1972) Effects of elemental phosphorus on marine life: collected papers resulting from the 1969 pollution crisis, Placentia Bay, Newfoundland. Circular No 2. Atlantic Regional Office, Research \& Development, Fisheries Research Board of Canada, Halifax, Nova Scotia

Johnstone K (1977) The aquatic explorers: a history of the Fisheries Research Board of Canada. University of Toronto Press, Toronto and Buffalo

Kurlansky M (1997) Cod: a biography of the fish that changed the world. Alfred A Knopf Canada, Toronto

Rozwadowski, H (2002) The sea knows no boundaries: a century of marine science under ICES. University of Washington Press, Seattle

Shelbourne JE (1964) The artificial propagation of marine fish. Adv Mar Biol 2:1-83

Stewart JE (1991) A brief review of the International Council for the Exploration of the Sea (ICES) on the occasion of the formation of the North Pacific Marine Science Organization. Can J Fish Aquat Sci 48:2543-2550 